\title{
LAJTÁR JÓZSEF
}

\section{A zsúfoltság csökkentésének gyakorlati megoldásai}

\begin{abstract}
A hazai börtönviszonyok az elmúlt évtizedekben sem voltak optimális szinten, ami nem azt jelentette, hogy összkomfortos elhelyezést kívánt nyújtani a büntetés-végrehajtás a fogvatartottaknak, hanem alapvető célkitüzésként fogalmazta meg, hogy a fogva tartás biztonságos és a jogszabályoknak megfelelő legyen. A zsúfoltság nemcsak napjainkra jellemző, hanem a korábbi években is időszakosan előkerülő probléma volt. Nem kell túl messzire viszszatekinteni ahhoz, hogy lássuk: 2008-ban az akkori politikai vezetés úgy döntött, hogy a hazai források hiánya miatt úgynevezett PPP-konstrukcióban két nagyobb befogadóképességü börtönt építtet. A létesítmények Tiszalökön és Szombathelyen épültek meg, és mind a két intézet a maga 800 fös befogadóképességével eredményesen szolgálta a biztonságosabb és jogszerübb elhelyezést. A 2010-es évtől átalakult az ítélkezési gyakorlat, módosult a büntetések jogszabályrendszere, és az átalakuló rendőrség egyre eredményesebben vette fel a harcot a bünelkövetökkel. A büntető törvénykönyv módosítása - figyelembe véve a három csapás törvényt is -, valamint a bűnelkövetők gyors és hatékony felderítése együttesen oda vezetett, hogy jelentősen megnövekedett a büntetés-végrehajtási intézetekben elhelyezett fogvatartottak száma. A nagyszámú fogvatartottból egyre nagyobb hányadot képviselt az előzetesben lévő fogvatartottak száma. A létszám növekedése azt idézte elö, hogy 2014-ben a büntetés-végrehajtási intézetekben nyilvántartott fogvatartotti létszám 18204 volt.

Ez a számadat akkor érdekes, ha figyelembe vesszük, hogy a rendelkezésre álló fogvatartotti férőhelyszám alig haladta meg a 12 500-at. Ez átlagosan 143 százalékos kihasználtságot jelentett. Mi járult hozzá a férőhelyszám ilyen szembetünő változásához?

Az Európai Unió gyakorlatában korábban is a CPT-ajánlás volt a meghatározó, azaz valamennyi fogvatartott részére a zárkában lévő felszerelési tárgyakon kívül legalább négy négyzetméter szabad mozgásteret kellett hagyni. Ez a magyar gyakorlatban eltérő volt, ugyanis az a miniszteri rendelet, amelyik meghatározta az egy fogvatartottra jutó zárkai szabad mozgásteret, feltételes módban rendelkezett e területről, általában három-három és fél négyzetméterben szabta meg. Ki kell emelni, hogy a börtönviszonyok és a férőhelybővítés
\end{abstract}


rendezése érdekében megfogalmazódott annak az igénye, hogy további új börtönt vagy börtönöket kell építeni. Elkészült egy 500 személy befogadására alkalmas, zöldmezős beruházás terve Szirmabesenyőre. A dokumentáció több év után vált véglegessé, ezért a költségvetési forrás rendelkezésre állásakor nem kezdődhetett el a beruházás, mert a tervek - a korábbi gyakorlatnak és jogszabályi környezetnek megfelelően - valamennyi fogvatartott részére három és fél négyzetméter szabad zárkateret biztosítottak. Az előző év decemberében azonnali intézkedésre volt szükség azért, hogy az új börtön megfeleljen a módosult jogszabályi feltételeknek, azaz közel másfél méterrel szélesebbre kellett tervezni az épületet.

A jogszabályi környezet változásáról szólva ki kell emelnünk a 2015-ben hatályba lépő bv.-kódexet, azaz a 2013. évi CCXL. törvényt a büntetések, az intézkedések, egyes kényszerintézkedések és szabálysértési elzárás végrehajtásáról. A törvény-előkészítők számtalan alternatív megoldást elemeztek, hogy a megnövekedett börtönkapacitás-kihasználtság - vagyis a túltelítettség - a jogszabály erejénél fogva is csökkenthetö legyen. A lehetőségek közül kiesett minden olyan elképzelés, amely lehetővé tette volna, hogy az elítélt a büntetése letöltése alatt az átlag állampolgárokkal azonos körülmények között éljen. A törvényalkotók elfogadtak azonban egy olyan megoldást, amely lazított a korábbi, csak börtönkörülmények között letölthető szabadságvesztés vagy büntetésletöltés elméletén, és a reintegrációs őrizet bevezetésével elfogadtak egy új büntetés-végrehajtási formát. Az európai gyakorlatban nem egyedülálló, hogy az elítélt elektronikus jeladó rendszer alkalmazásával a lakókörnyezetében tölti le a büntetését. A magyarországi gyakorlatban ez első alkalommal a rendőrség kezdeményezésére valósult meg olyan módon, hogy a bírói döntés alapján házi őrizetben lévő terhelteket elektromos jeladó rendszerrel szerelték fel, a mozgási körzetüket szigorú meghatározás mellett rögzítették, és - szükebb értelemben véve - a lakóegységüket jelölték ki a tartózkodás helyéül.

Mérföldkőnek számított tehát az elektronikus házi őrizeti rendszer kiépítése és bevezetése. A bírói gyakorlatban korábban is meghatározták, hogy a házi örizetben lévő személy hol köteles tartózkodni, és általánosságban - az orvosi ellátás igénybevétele, a bírósági, ügyészségi vagy rendőrségi megjelenés kivételével - a lakhelyelhagyás tiltva volt. A szabályok megtartását, azaz a házi őrizetesek jogkövető magatartását a rendőrség élőerővel ellenőrizte, azaz a rendőrjárőrök gépkocsival megközelítették az adott tartózkodási helyet, meggyőződtek arról, hogy a gyanúsított a megfelelő helyen tartózkodik, majd folytatták a járőrözési útvonalukat. Ez a gyakorlat a társadalom számá- 
ra jelentős költséggel járt, ugyanis a drága élőerő mellett a gépjármü üzemeltetéséhez kapcsolódó költségek is növelték a kiadást. A kiugrás oka az elektronikus házi őrizeti rendszer volt, amely gyakori ellenőrzés nélkül, folyamatos információt továbbított a rendőrség ügyeleti központjainak, így valamennyi megyei rendőr-főkapitányság „online” szerzett tudomást a házi örizetes tartózkodási helyéröl. A rendszer nemcsak gazdaságilag, hanem szakmailag is jól vizsgázott, ennek is köszönhető, hogy a bírói gyakorlatban kiterjedtté vált az elektronikus házi őrizeti eszköz alkalmazása.

A büntetés-végrehajtási törvény hatálybalépésének idejére már egy ellenörzött, a magyar körülmények között jól müködő elektronikus házi örizeti rendszer állt rendelkezésre. Ezzel az eszközparkkal kockázatmentesen lehetett megkezdeni az úgynevezett reintegrációs őrizetet. Lényeges megemlíteni, hogy ezzel a büntetés-végrehajtási formával a törvényalkotó nem puhította fel korábbi elképzeléseit, ugyanis szigorú feltételekhez kötötte, hogy milyen büncselekményt elkövető személyek fejezhetik így be a büntetésük letöltését. A teljesség igénye nélkül ki kell emelni, hogy csak olyan bünelkövetö bocsátható reintegrációs örizetre, akinek az elkövetett büncselekmény tárgyi súlya alapján a büntetési tétele nem haladta meg az öt évet, a magaviselete nem volt kifogásolható a büntetés letöltésének eltelt időszakában, és a hátralévő büntetési idő nem haladja meg a hat hónapot. Ez annyit jelent, hogy a reintegrációs őrizetre bocsátott fogvatartott a büntetése utolsó hat hónapját családi környezetben tölti le úgy, hogy a mozgási körzete kötött és a büntetés-végrehajtási bíró által meghatározott.

A társadalomba való visszavezetés valamennyi fogvatartott esetében alapvető közösségi érdek. Ennek a leghatékonyabb módszere lehet, ha az elítélt a családja környezetében tapasztalja, hogy mi változott abban az időben, amíg ő büntetés-végrehajtási intézetben volt, hogyan alakult át a kisebb és nagyobb közösség. Az elítélt érintkezhet közvetlenül a jogkövető állampolgárokkal, munkát végezhet, amelyből jövedelemhez jut, és gondoskodhat saját maga és a családja megélhetéséről. A reintegrációs őrizet alkalmazása a 2015. április 1-jei hatálybalépés után gyorsan elfogadottá vált a büntetés-végrehajtási bírók körében. Az elmúlt fél évben a reintegrációs örizetben lévő fogvatartottak száma nem haladta meg a százat, folyamatosan a hetven és kilencven közötti örizetesszám volt az általános.

A büntetés-végrehajtási szervezetnek van annyi eszköze, hogy az egy időben fogva tartott és a reintegrációs örizetre bocsátható személyek kivétel nélkül ezzel a könnyített büntetés-végrehajtással fejezzék be a jogerős ítéletük letöltését. A kialakult gyakorlat előnye, hogy az elektronikus házi őrizeti, va- 
lamint a reintegrációs őrizeti rendszer központja azonos, így a legnagyobb értéket képviselő berendezést nem kellett megduplázni, miközben akadálymentesen kiszolgálhatja a rendőrség és a büntetés-végrehajtás igényeit.

A jelenlegi elemzések alapján megállapítható, hogy a teljes fogvatartotti létszámból maximum háromszáz-háromszázötven személy helyezhető reintegrációs őrizetbe. Ez kedvezőbbé teheti a börtönök telítettségi mutatóját, de nem oldja meg a túlzsúfoltságot. Az elmúlt évben hozott intézkedések nyomán a korábbi 143 százalékos férőhely-kihasználtság napjainkra 126-128 százalékra mérséklődött.

Nézzük, melyek voltak ezek az intézkedések! A büntetés-végrehajtás szakemberállománya idejében észlelte, hogy tényleges férőhelybővítés nélkül nem lehet megoldani a túlzsúfoltságból eredő problémát. Pufferként hatott erre a folyamatra a nemzetközi ítélkezési gyakorlat, amely több, magyar börtönben büntetését töltő elítélt egyéni kezdeményezése nyomán elmarasztaló ítéletet hozott az ország számára. Az elmarasztalás vonatkozott arra, hogy a jelenlegi túlzsúfolt börtönhelyzetet belátható időn belül meg kell oldani, és egyúttal a keresettel élö fogvatartottak (vagy volt fogvatartottak) részére kártérítést állapított meg.

A szervezet a férőhelybővítést a korábban börtönként vagy fogházként használt épületek felújításával kezdte meg. Martonvásár területén egy alacsony biztonsági fokozatú intézet, illetve objektum müködött a nyolcvanas-kilencvenes években, de ezt felszámolták, és az épület megközelítőleg tizenöt évig használaton kívül volt. Ebben az objektumban ki lehetett alakítani egy 127 személyes elhelyezési körletet, szintén alacsony biztonsági fokozattal, megfelelő, kulturált környezetben. A beruházás 2015-ben fejeződött be, és az épületet március 23-án adták át a Közép-dunántúli Büntetés-végrehajtási Intézet részére. A Budapesti Fegyház és Börtön területén az úgynevezett csillag egyik szárnya az amortizálódás és állagromlás miatt használaton kívül került, ezért ennek a felújítását 2014-ben megkezdte a büntetés-végrehajtási szervezet. Ebben a körletrészben 45 fogvatartott elhelyezése valósult meg, de ki kell emelni, hogy a negyvenötből hét személy részére úgynevezett hosszú idős speciális rezsimü körletet alakítottak ki. A legnagyobb kapacitásbővülés a Szombathelyi Országos Bv. Intézet területén történt, amikor is egy 396 személy befogadására képes épületet újítottak fel, ennek fele börtönfokozatú, míg a másik fele fogházminősítésű elítéltek elhelyezésére alkalmas. A 396 személyes új terület kialakítása mellett a szombathelyi intézet területén müködő, PPP-konstrukcióban megépített három börtönépület alkalmas arra, hogy további 280 ember elhelyezése megtörténjen anélkül, hogy sérülne a 
CPT által ajánlott, fogvatartottankénti négy négyzetméter szabad alapterületre vonatkozó elöírás.

Valamennyi felújitás esetén, amikor is új féröhelyeket alakítottak ki, több közös jellemző állapítható meg. Mint már említettük: meglévő, korábban börtönként funkcionáló, vagy arra alkalmas épületek felújítására került sor. A felújítások idején fogvatartotti munkáltatás is történt, ugyanis a Budapesti Fegyház és Börtön területén fogvatartottak távolították el a régi vakolatot és a nem hasznosítható szerelvényeket, a martonvásári objektumban a fogvatartottak előkészítő és tereprendezési munkát végeztek, valamint elbontották a felesleges és a terület használhatóságát akadályozó építményeket. Tereprendezési és elökészítő munkát végeztek a fogvatartottak a szombathelyi objektum területén is.

Jelenleg az Állampusztai Országos Bv. Intézet solti objektumának bővítése zajlik, az átadás után további 117 személy helyezhető el. Meglévő épületek és büntetés-végrehajtási vagyon felhasználásával még további férőhelybővítésre kerül sor a Hajdú-Bihar Megyei Bv. Intézetben. A szervezet saját forrásból, fogvatartotti munkáltatással újította fel a Váci Fegyház és Börtön egyik épületét, amely 32 elítélt befogadására alkalmas. Ezen a területen még további szerény bővítési lehetőségek vannak, ez ütemesen megvalósítható a 2016-os költségvetési évben.

A jelzett férőhelybővítések is hozzájárultak ahhoz, hogy szembetünően csökkent a magyar börtönök túltelítettsége. Szignifikáns különbség mutatkozik a 142-143 és a 126-128 százalékos kihasználtság között. Ehhez hozzájárul, hogy a fogvatartotti létszám átlagosan legalább négyszázzal alacsonyabb, mint a 2014-es átlagos létszám. Ebből megközelítőleg százan vannak reintegrációs őrizetben. A háromszáz fős létszámcsökkenés elsősorban az előzetes letartóztatásban lévők számának mérséklődéséből adódik.

A rendelkezésre álló épületvagyon hasznosításával, valamint a jogszabály által lehetővé tett büntetés-végrehajtási módszerek kiszélesítésével a büntetés-végrehajtási intézetek túltelítettsége eddig a szintig volt csökkenthető. Megállapítható, hogy továbbra is nagyjából hatezer-ötszáz elítélt részére kell férőhelyet nyújtani ahhoz, hogy a jogszabályoknak és a CPT-ajánlásnak megfelelő alapterület minden fogvatartottnak meglegyen.

Ezt az igényt egyféleképpen lehet kielégíteni: új bv. intézetek megépítésével. Az új elhelyezési lehetőségek zöldmezős beruházásként valósulhatnak meg, ehhez egyrészt szükség van megfelelő, a kor követelményei által elöírt engedélyeztetési és kivitelezési tervekre, építési területre és nem elhanyagolható tényezőként akkora forrásra, amelyből megvalósítható a hatezer-hatezer- 
ötszáz fős férőhelybővítés. Ez a férőhely-kapacitás a már említett szirmabesenyői ötszáz fös férőhely mellett további nyolc ötszáz személyes és egy ezerszemélyes börtön megépítésével érhető el. Számítunk arra, hogy a fogvatartotti átlaglétszám nem emelkedik a 2015-ben tapasztalható szint fölé.

A beruházásokhoz szükséges építési terület megszerzése történhet vásárlással, amelyhez költségvetési forrást kell rendelni. Ez lényegesen megnöveli az épület bekerülési költségét, ezért célszerü inkább olyan területszerzési módot választani, amely a lehető legkisebb terhet rója a központi költségvetésre. Véleményünk szerint erre alkalmas egy olyan önkormányzati pályázat kiírása, amelyben felkérjük a helyhatóságokat, hogy ajánljanak fel olyan telket, amely megfelel börtönépítési célokra, valamint az ajánlati felhívásban közzétett követelmények szerint teremtsék meg a müködéshez szükséges feltételeket.

Jogosan vetődik fel a kérdés, vajon milyen érdeke füződik az önkormányzati rendszernek a börtönépítéshez és a telekfelajánláshoz. Meggyőződésem, hogy valamennyi önkormányzat képes megfelelően mérlegelni, hogy egy ilyen beruházás mit hoz a településnek, és milyen hátrányokkal kell szembesülnie.

Kézenfekvő, hogy a hátrányok mérlegelése döntésbefolyásoló tényező. A börtönök társadalmi megítélése erősen szubjektív. A börtön szó rossz képzetet kelt: egy zord, zárt intézmény, amelytől jobb, ha távol vannak Magyarország polgárai. A büntetésüket letöltő fogvatartottak szabadulásuk után megjelennek a település közterületein, ez pedig a szubjektív megítélés alapján szintén a közbiztonságra veszélyes tényező lehet. Ugyanez a hozzáállás vonatkozik az eltávozásra induló fogvatartottakra is.

Véleményem szerint a pozitív hatások ennél lényegesen megalapozottabbak, és a település szempontjából fontosabbak. Első helyre kell sorolni azt az érvet, hogy egy ötszáz személyes börtön kétszázötven helyi vagy környékbeli lakos foglalkoztatásával jár, akár kétszázötven család részére nyújthat biztos megélhetést. A börtön a fogvatartottaknak teljes körü ellátást kell hogy kínáljon, ezért a szervezett és jól működő belső ellátási rend mellett is igénybe kell venni külső szolgáltatásokat, be kell szerezni bizonyos áruféleségeket, amelyek a teljes ellátás alapanyagául szolgálnak. A bv.-kódex előírásai alapján valamennyi munkaképes fogvatartottat foglalkoztatni kell, ezért olyan munkahelyeket kell teremteni, ahol ésszerü és célszerü termelő tevékenységet végezhetnek az elítéltek. Ez a termelő tevékenység nem képzelhető el hozzáértő és szakképzett civil munkavállalók nélkül, ez további munkáltatásra, foglalkoztatásra ad lehetőséget. 
Egy ötszáz személyes börtön nagyüzemnek minősül, ezért olyan infrastruktúrára van szüksége, amely az összes felvetődő igényt korszerủen, környezetkímélőn, hosszú távon kiszolgálja. Ez a fejlesztés nem öncélú, hiszen a beruházás a település javát is szolgálja. Több településen gond idénymunkásokat találni a mezőgazdasági termékek előállításához. A betakarításhoz a fogvatartottak egy része kiválóan alkalmazható. A teljesség igénye nélkül megállapítható, hogy a tényszerü érvek amellett szólnak, hogy egy település kockázatmentesen vállalhat börtönépítést, és ajánlhat fel telket, mert ez a fejlödést garantálja, egyúttal pedig a munkahelyteremtéssel csökkenti az elvándorlásból adódó lakosságszám-csökkenést.

A megfogalmazott vélemények figyelembevételével készült el az ajánlati felhívás, amelyet valamennyi önkormányzat megkapott. A szkeptikusok temették a gondolatot, hogy az önkormányzatok ilyen célra ajánlatot fognak tenni. Az optimisták tábora viszont biztos volt abban, hogy nagy népszerüségnek örvend majd az ajánlat, és az önkormányzatok élnek a lehetőséggel.

Az optimisták nyertek. Negyven olyan pályázat érkezett be, amely megfelelt a kí́rásban szereplő követelményeknek, azaz a negyvenből bármelyiket ki lehetett volna választani ahhoz, hogy ott börtön épüljön.

Nézzük, mik voltak az ajánlati felhívásban szereplö kívánalmak! A szakemberek véleménye szerint tíz olyan alkalmassági kritérium megállapítása indokolt, amely alkalmassá teheti a felajánlott telket a beruházáshoz. A teljesség igénye nélkül néhányat kiemelek: börtönt azon a területen kell építeni, ahol a legnagyobb a bűnügyi fertőzöttség és ahonnan a legtöbb elítélt kerülhet az intézetbe. Olyan helyen kell új intézetet kialakítani, ahol a fogvatartotti férőhely-lefedettség a legkisebb, a felmerülő szükséglet pedig a legnagyobb. A statisztikai adatok alapján kiemeltük, hogy a dél-dunántúli, dél-alföldi, észak-alföldi, észak-magyarországi, valamint a közép-magyarországi régió, azon belül néhány kistérség jöhet számításba.

Fontosnak tartottuk, hogy a tulajdoni viszony rendezett és egyértelmű legyen, azaz a terület az önkormányzat százszázalékos tulajdona legyen. A területen nem lehet épület, építmény, legalább négy hektár legyen, és közmüvesített, vagy az önkormányzat vállalja a közművesítést. Legyen ivóvíz, szennyvízelvezetés, villamosenergia- és földgázellátás, továbbá legyen meg a kommunális hulladék elszállításának valamennyi feltétele. Véleményünk szerint a tíz kritérium célszerüen kiegészíthető öt olyan feltétellel, amely előnyt nyújt az ajánlat számára. Ezek közé sorolható az óvodai, iskolai, illetve kórházi ellátás helyzete, valamint a szociális feltételek rendelkezésre állása. Az önkormányzat közremúködik vagy hozzájárul az objektum kialakítá- 
sához vagy müködtetéséhez. A terület könnyen megközelíthetö legyen az ország bármely részéből (tömegközlekedés, közúti közlekedés stb.). A terület legyen alkalmas arra, hogy a fogvatartottak legalább felét külső munkahelyen is foglalkoztatni lehessen.

Az egyértelmủ alkalmassági és egyéb követelmények ellenére bizonyos vállalkozások megkísérelték forgalomképtelen területek értékesítését, amelyek alkalmatlanok börtön építésére.

Az önkormányzati felajánlások összességében megalapozottak voltak, kellő mérlegelés után nyújtották be őket. Volt olyan polgármester, aki interneten véleménynyilvánításra kérte a lakosságot, hogy egyetértene-e ilyen elképzeléssel. Valamennyi ajánlattevő önkormányzat valamilyen módon szondázta a lakosságot, kikérte a véleményüket. Ezek a felmérések is azt támasztották alá, hogy a szubjektív elöítéletek háttérbe szorulnak, és a többség a település fejlődését látná egy ilyen beruházásban. Nem tételezhető fel azonban, hogy a benyújtott pályázatok után valamennyi település minden lakosa örömmel fogadta volna, hogy a saját önkormányzata pályázott. E kisebbségben lévő véleménynyilvánítók az aggályaikat fejezték ki, ezekből a már említett szubjektív elemek tükröződtek vissza.

Az önkormányzatok által felajánlott ingatlanok kielégítik az építési területre vonatkozóan megfogalmazott igényt. Ezért nagyobb ráfordítás nélkül elérhető, hogy a szükséges férőhelybővítés határidőre megvalósul. Nem kevésbé fontos tényező, hogy milyen tervek alapján készül el az objektum. Egy kiemelkedő szinten megtervezett épület látványossága is lehet egy adott területnek, tájegységnek. Fel kell azonban tenni a kérdést, hogy ez cél-e a beruházás során. Véleményem szerint nem. Az a megfogalmazható cél, hogy korszerü, biztonságos, takarékosan megvalósítható és üzemeltethető legyen az épület, amelyben nem a komfortbesorolás a meghatározó, hanem az, hogy a fogvatartottak emberi körülmények között töltsék a büntetésüket. Egy börtönnek kívülről se kell kitűnő esztétikai színvonalúnak lennie, azt kell tükröznie, hogy oda a társadalom azon tagjai kerülnek, akik szembefordulnak a társadalmi normákkal.

A kívánalmaknak akkor is megfelelhetünk, ha úgynevezett típustervek alapján készítjük el a börtönobjektumokat. A tervező így figyelembe veheti, milyen szakmai, biztonsági, munkáltatási és foglalkoztatási igények fogalmazódnak meg, az épület hogyan tudja kiszolgálni ezeket, és megteremteni a törvényes elhelyezés feltételeit. Véleményem szerint három típusú tervet kell készíteni, egy nagy befogadóképességü, börtön- és fegyházminősítésü, egy ötszáz személy befogadására alkalmas, kiemelkedő biztonsági előírásoknak 
megfelelö, valamint egy ötszáz személyes, alacsony biztonsági kívánalmaknak megfelelő épület dokumentumát. A tervező kiválasztása a hatályos jogszabályok alapján kell hogy történjen, azaz nyílt közbeszerzési eljárás nyertese lehet az, aki ezt a munkát elvégzi. Célszerü, hogy egy tervező tervezze meg valamennyi objektumot, így elérhető, hogy azok az elemek, amelyek azonosak lehetnek, vagy kell hogy legyenek a különböző épületekben, azok az előzetes elképzelésnek megfelelően valósuljanak meg. A közbeszerzési eljárás kezdete a 2015-2016-os költségvetési év kell hogy legyen úgy, hogy a tervezés 2016 végére befejeződjön. Elengedhetetlen a dokumentáció sokoldalú zsưrizése, csak akkor kiküszöbölhető, hogy a használatba vétel után derüljenek ki a feladat végrehajtását akadályozó vagy nehezítő körülmények.

Lényeges elemnek tartom, hogy az elkészülő típusterveknek komplexeknek kell lenniük, kell hogy készüljön engedélyezési és kivitelezési terv, majd később a megvalósulást ugyanígy dokumentálni kell. A komplexitás azt is jelenti, hogy a biztonsági rendszer és a berendezési terv is része ennek a dokumentumnak.

A tervezés folyamán figyelembe kell venni a foglalkoztatás és munkáltatás feltételeit, így elöre fel kell mérni, milyen tevékenység telepíthető az adott bv. intézetbe, és az üzemcsarnokot ahhoz kell kialakítani.

Felvetődhet, hogy egy ilyen volumenü beruházás milyen forrásból finanszírozható. Első pillanatban mindenkiben felötlik az úgynevezett PPP-konstrukcióban megvalósult beruházások emléke. Az épületek kialakítása határidőre, jó minőségben megtörtént, a bekerülési költség azonban másfél-két évtizedig olyan terhet ró a központi költségvetésre, amelyet a megrendelő nem tud befolyásolni. A büntetés-végrehajtás által 2008-ban kötött ilyen szerződései tizenöt év futamidő után járnak le. Az üzemeltetés lényegesen drágább, mintha a megrendelő önmaga tenné, igaz, ez a tevékenység nem hagy maga után kívánnivalót. Nem kis erőfeszítéseket tesznek az üzemeltetők azért, hogy a munkáltatás kitünő színvonalon történjen meg, de ennek az árát szintén a költségvetés állja. A beruházó által igénybe vett hitelkonstrukció hosszú távra meghatározza a törlesztőrészlet nagyságát, és ilyenkor a beruházónak nem kerül semmibe a költségesebb hitel. Bizonyíték erre a büntetés-végrehajtás tapasztalata: ma lényegesen olcsóbb hitellel ki lehetne váltani a 2008-ban még olcsónak számító, nyolc százalék kamatú hitelt, de ezt a forrást nyújtó pénzintézet és a szerződés nem teszi lehetővé. Véleményem szerint tehát ilyen tapasztalatok után nem szabad effajta konstrukcióban gondolkodni.

Elképzelhető-e, hogy a büntetés-végrehajtás vesz fel kedvező kamatozású hitelt, és ebből megvalósítja a beruházásokat? Első megközelítésben ez meg- 
valósítható, jó elképzelésnek tünik. De ha figyelembe vesszük, hogy az így felvett hitel ugyanúgy rontja a központi költségvetés adott évi pozícióját, mintha maga a költségvetés finanszírozta volna, akkor ezt a gondolatot is el kell vetni.

Meg kell vizsgálni, van-e az Európai Unión belül olyan hitelkonstrukció, amely nem befolyásolja az ország költségvetését, miközben kedvező feltételekkel adhat forrást. Az elmúlt időszakban ilyen megoldást nem találtak. Marad a költségvetési forrásbevonás. Ez a finanszírozási megoldás két-három éven keresztül kiugró terhet ró a központi költségvetésre, a feltételek megteremtése után azonban már csupán az üzemeltetéshez kapcsolódó kiadásokat kell finanszírozni. A jelenlegi helyzetben ez a megoldás tünik a legkézenfekvőbbnek, és az egyetlen megvalósítható kezdeményezésnek.

Komolyan kell venni, hogy a szabaduló vagy a még büntetésüket töltő fogvatartottak jogorvoslati kérelmet nyújtanak be a rossz fogva tartási körülmények miatt, és a bíróság döntése nyomán a költségvetésnek kell állnia a kártérítésüket. Így inkább azokat a megoldásokat kell preferálni, amelyek társadalmi hasznossága is mérhető. A bírság helyett bv. intézetek megépítésére kell fordítani a költségvetési forintokat, és ezzel megszüntethető a túlzsúfoltság.

Felvetődik a kérdés: van-e realitása annak, hogy 2019-re megszünik a jelenlegi magyarországi fogvatartotti férőhelyhiány, vagy ez megvalósíthatatlan? A célkitüzés reális, megalapozott az az elképzelés, hogy a beruházáshoz szükséges forrás három-négy évig meglegyen, és a 2015-ös bázisáron számított előzetes költségigény, azaz az Országgyülés jóváhagyja a szükséges ötvenöt-hatvanmilliárd forintot.

\section{Összegzés}

Úgy értékelem, hogy a megfogalmazott tervek és elképzelések nem a luxuselhelyezést, hanem a törvényes feltételek megteremtését teszik lehetővé a fogvatartottiférőhely-bővítési javaslatban. A megépülő börtönök alapjai annak a konzekvens és szigorodó bűnmegelőzési és büntetési gyakorlatnak, amelynek célja, hogy a társadalom tagjai törvénytisztelővé váljanak, és elfogadják az együttélés szabályait. Ehhez költségvetési áldozatot kell hozni, amely azonban hosszú távon megtérül, hiszen családok százainak teremt biztos megélhetést és anyagi biztonságot. 